\title{
Mortality in heart failure patients
}

\author{
Ibadete Bytyçi, Gani Bajraktari
}

Clinic of Cardiology and Angiology, University Clinical Centre of Kosova; Prishtina-Republic of Kosovo

\section{ABSTRACT}

Heart failure (HF) is a clinical syndrome, which is becoming a major public health problem in recent decades, due to its increasing prevalence, especially in the developed countries, mostly due to prolonged lifespan of the general population as well as the increased of HF patients. The HF treatment, particularly, new pharmacological and non-pharmacological agents, has markedly improved clinical outcomes of patients with HF including increased life expectancy and improved quality of life. However, despite the facts that mortality in HF patients has decreased, it still remains unacceptably high. This review of summarizes the evidence to date about the mortality of HF patients. Despite the impressive achievements in the pharmacological and non-pharmacological treatment of HF patients which has undeniably improved the survival of these patients, the mortality still remains high particularly among elderly, male and African-American patients. Patients with HF and reduced ejection fraction have higher mortality rates, most commonly due to cardiovascular causes, compared with patients HF and preserved ejection fraction. (Anatolian J Cardiol 2015; 15: 63-8)

Key words: heart failure, mortality, race, elderly, gender

\section{Introduction}

Heart failure (HF) is a clinical syndrome, which is becoming a major public health problem in recent decades, due to its increasing prevalence, especially in the developed countries $(1,2)$. The increased prevalence is mostly due to prolonged lifespan of the general population in these countries $(2,3)$ as well as the increased life expectancy of HF patients. The life expectancy is prolonged in HF patients, mainly due to the improved pharmacological and non-pharmacological treatment (4). The etiology of $\mathrm{HF}$ is different in different countries and different populations, but nowadays arterial hypertension and coronary artery disease (CAD) are predominant etiologic factors (5). In the past, HF with reduced left ventricular ejection fraction (HFrEF) was the most commonly diagnosed clinical entity in HF patients. However, with the improvement of diagnostic tools, especially with the introduction of new echocardiography modalities, recent clinical and epidemiologic studies have shown that nearly half of $\mathrm{HF}$ patients have preserved $\mathrm{EF}$, and this clinical entity of $\mathrm{HF}$ with preserved left ventricular $\mathrm{EF}(\mathrm{HFpEF})$ was introduced as $(6,7)$. $\mathrm{HF}$ is one of the most frequent causes of hospitalizations and multiple hospitalizations (8), as well as of high costs (9). Recent studies have shown that the HF treatment, particularly, new pharmacological agents, implantation of intra-cardiac defibrillators (ICD), cardiac resynchronization therapy (CRT) and other surgical procedures, has markedly improved clinical outcomes of patients with HF including increased life expectancy and improved quality of life $(4,10)$. However, despite the facts that mortality in HF patients has decreased, it still remains unacceptably high (3).

\section{Trends of mortality in patients with heart failure}

Many studies have addressed trends in the mortality and survival patients with $\mathrm{HF}$ comparing different time periods in different countries (Table 1). Based on the Framingham Heart Study, the mortality rate after diagnosis of $\mathrm{HF}$ in the USA was around $10 \%$ at 30 days, $20-30 \%$ at 1 year and $45-60 \%$ over 5 years of follow-up (11). Conversely, the Rotterdam study, which included HF patients in Europe, showed a lower mortality, with $11 \%$ and $41 \%$ mortality rates at 1 year and 5 years of follow-up, respectively (12).

Most epidemiological studies demonstrated a trend toward a decrease in mortality rates in HF patients in the last decades $(3,4$, 13). From the 1959-1969 to 1990-1999 time periods, mortality in HF patients is decreased from $70 \%$ to $59 \%$ in man, and from 57 to $45 \%$ in women (3). Hillingdon-Hasting Study demonstrated that 6-month mortality after diagnosis of HF decreased significantly $(p<0.001)$ from $26 \%$ in $1995-1997$ to $14 \%$ in $2004-2005$ (14). Similarly, the

Address for Correspondence: Dr. Gani Bajraktari, MD, PhD, FACC, Clinic of Cardiology and Angiology

University Clinical Centre of Kosova, 'Rrethi i Spitalit', p.n., 10000, Prishtina, Republic of Kosovo

Phone: + 37745800808 E-mail: gani.bajraktari@uni-pr.edu

Accepted Date: 23.06.2014 Available Online Date: 19.08.2014

(C) Copyright 2015 by Turkish Society of Cardiology - Available online at www.anakarder.com DOI:10.5152/akd.2014.5731 
Table 1. The mortality rate in heart failure patients in different period of time

\begin{tabular}{|c|c|c|c|c|c|}
\hline Author & Study & Number of patients & Period of time & Mortality & $P$ \\
\hline Levy et al. (11) & $\begin{array}{l}\text { Framingham Heart } \\
\text { Study, USA } \\
\text { (Population Based } \\
\text { cohort) }\end{array}$ & 1075 & $\begin{array}{l}1950-1959 \\
1990-1999\end{array}$ & $\begin{array}{l}1 \text { year, M: } 30 \%, \text { F: } 28 \% \\
5 \text { years, M: } 70 \%, F: 57 \% \\
1 \text { year, M: } 28 \%, F: 24 \% \\
5 \text { years, M: } 57 \%, F: 45 \%\end{array}$ & $\begin{array}{c}0.01, \text { for } M \\
0.02, \text { for } F\end{array}$ \\
\hline Roger et al. (17) & $\begin{array}{l}\text { Olmsted Country } \\
\text { MN, USA } \\
\text { (Population Based } \\
\text { cohort) }\end{array}$ & 4537 & $\begin{array}{l}1979-1984 \\
1996-2000\end{array}$ & $\begin{array}{l}1 \text { year, M: } 30 \%, \text { F: } 20 \% \\
5 \text { years, M: } 65 \%, F: 51 \% \\
1 \text { year, M: } 21 \%, F: 17 \% \\
5 \text { years, M: } 50 \%, F: 46 \%\end{array}$ & $\begin{array}{l}<0.001 \text {, for } M \\
<0.001, \text { for } F\end{array}$ \\
\hline Loh et al. (4) & $\begin{array}{l}\text { Ahmanson-University } \\
\text { of California } \\
\text { Los Angeles Cardio- } \\
\text { myopathy Centre }\end{array}$ & 2507 & $\begin{array}{l}1993-1998 \\
2005-2010\end{array}$ & $\begin{array}{l}1 \text { year, } 20.6 \% \\
3 \text { years, } 36.4 \% \\
1 \text { year, } 17.8 \% \\
3 \text { years, } 31.5 \%\end{array}$ & $\begin{array}{l}0.04, \text { for } 1 y \\
0.02, \text { for } 3 y\end{array}$ \\
\hline Mehta et al. (14) & $\begin{array}{l}\text { Hillingdon-Hasting } \\
\text { study, England } \\
\text { (Population Based } \\
\text { cohort) }\end{array}$ & 948 & $\begin{array}{l}1995-1997 \\
2004-2005\end{array}$ & $\begin{array}{l}6 \text { months, } 22 \% \\
6 \text { months, } 16 \%\end{array}$ & $<0.001$ \\
\hline Laribi et al. (15) & $\begin{array}{l}\text { Seven European } \\
\text { Countries } \\
\text { (Population Based } \\
\text { cohort) }\end{array}$ & & $\begin{array}{l}1987 \\
2008\end{array}$ & $\begin{array}{l}54.2 / 100000 \\
32.6 / 100000\end{array}$ & $<0.001$ \\
\hline Gomez-Soto et al. (13) & $\begin{array}{l}\text { Framingham criteria } \\
\text { HUPR, Spain }\end{array}$ & 4793 & $\begin{array}{l}2000 \\
2007\end{array}$ & $\begin{array}{r}1 \text { year, M: } 34.8 / 100 \\
\text { F: } 27.0 / 100 \\
1 \text { year, M: } 33.4 / 100 \\
\text { F: } 23.7 / 100\end{array}$ & $\begin{array}{l}<0.05, \text { for } M \\
<0.05, \text { for } F\end{array}$ \\
\hline
\end{tabular}

Framingham heart study documented that 30-day, 1-year and 5 -year mortality among men with HF declined ( $p=0.01$ ) from $12 \%$, $30 \%$ and $70 \%$ in the period $1959-1969$, to $11 \%, 28 \%$ and $59 \%$ in the period 1990-1999. The mortality rate among women was also decreased $(p=0.02)$ from $18 \%, 28 \%$ and $57 \%$ in the period 1959 1969 to $10 \%, 24 \%$ and $45 \%$ in the period $1990-1999(3,11)$. Along the same lines, the study by Loh et al. (4) showed a significant decrease of 3 years mortality among patients with HF with reduced $\mathrm{EF}$ from $36 \%$ in the time period between 1993 and 1998 to $31 \%$ in the time period between 2005 and 2010 ( $p=0.02)$. Moreover, a recent study by Laribi et al. (15) found that mortality decreased in seven European countries (Germany, Greece, England and Wales, Spain, France, Finland and Sweden) from 52 per 100000 inhabitants in 1987, to 33 per 100000 inhabitants in 2008.

In summary, the overall survival and lifespan of HF patients increased in last decades, particularly after 1998 (4, 16). From 1989-1991 to 1999-2001, the survival of patients with HF at 30 days, 1 year and 5 years, improved by $5 \%, 10 \%$ and $9 \%$, respectively (16). Data from the Framingham study showed comparable improvement in the long-term survival in both man and women (12\% per decade) after HF onset (11). Likewise the Olmsted Country study underscored the improvement of 5-year survival, from $43 \%$ during the period of time $1979-1984$ to $52 \%$, during the period of $1996-2000(p<0.001)$. This survival improvement was better in women than men (17). The study by Barker et al. (18) showed an improvement of survival in elderly ( $\geq 65$ years) patients after the HF diagnosis, by $33 \%$ in men and $24 \%$ in women from mid-1970s to mid-1990s.

\section{In-hospital mortality in patients with heart failure}

Epidemiological studies have shown that despite increased total number of HF hospitalizations and readmissions rates in last decades (19), the mean length of hospital stay as well as the in-hospital mortality were significantly decreased (Table 2) $(8,20)$. Data from the National Hospital Discharge Survey showed that the total number of hospitalizations for HF in USA was tripled from 1979 to 2004 (21). Likewise, Blecker et al. (22) showed that hospitalizations for HF in USA increased from 2.75 million in 2001 to 3.15 million in 2009.

The Based on Centers for Medicare and Medicaid Services (CMS) data, showed that in-hospital mortality rate in HF patients during the 16 years study period, declined by $4.3 \%$, from 1993 to $2008(8.5 \%$ to $4.2 \%, \mathrm{p}<0.001)(23)$. The mean length of hospital stay also decreased $(p<0.001)$ from 6 days in 1987-1991 to 4 days 
Table 2. Trends of mortality in heart failure related hospitalization, in different period of time

\begin{tabular}{|c|c|c|c|c|c|}
\hline Author & Setting & $\begin{array}{c}\text { Number of } \\
\text { hospitalizations }\end{array}$ & $\begin{array}{l}\text { Period of } \\
\text { time }\end{array}$ & $\begin{array}{l}\text { Mean length } \\
\text { of stay }\end{array}$ & $\begin{array}{l}\text { In-hospital } \\
\text { mortality }\end{array}$ \\
\hline Kosiborod et al. (25) & CMS, USA & 3957520 & $\begin{array}{l}1992 \\
1999\end{array}$ & $\begin{array}{l}7.3 \text { days } \\
5.5 \text { days }\end{array}$ & $\begin{array}{l}30 \text { days: } 11.0 \% \\
1 \text { year: } 32.5 \% \\
30 \text { days: } 10.3 \% \\
1 \text { year: } 31.7 \%\end{array}$ \\
\hline Bueno et al. (22) & $\begin{array}{l}\text { MEDPAR, CMS } \\
\text { USA }\end{array}$ & $\begin{array}{l}498500 \\
412614 \\
\end{array}$ & $\begin{array}{l}1993 \\
2003\end{array}$ & $\begin{array}{l}8.8 \text { days } \\
6.3 \text { days }\end{array}$ & $\begin{array}{l}8.50 \% \\
4.20 \%\end{array}$ \\
\hline Schaufelberger et al. (24) & $\begin{array}{l}\text { National Hospital } \\
\text { Discharge Register } \\
\text { Sweden }\end{array}$ & 156919 & $\begin{array}{l}1988 \\
2000\end{array}$ & & $\begin{array}{l}1 \text { year } \\
\text { age } 45-54, \mathrm{M}: 23 \% \text {, F: 31\% } \\
\text { age } 75-84, \mathrm{M}: 48 \% \text {, F: } 41 \% \\
1 \text { year } \\
\text { age } 45-54, \mathrm{M}: 9 \%, \mathrm{~F}: 8 \% \\
\text { age } 75-84, \mathrm{M}: 36 \%, \mathrm{~F}: 29 \%\end{array}$ \\
\hline Blackledge et al. (23) & $\begin{array}{l}\text { Office of National } \\
\text { Statistics } \\
\text { England }\end{array}$ & $\begin{array}{l}498500 \\
413614\end{array}$ & $\begin{array}{l}1993-1994 \\
2000-2001\end{array}$ & $\begin{array}{l}9 \text { days } \\
9 \text { days }\end{array}$ & $\begin{array}{l}22 \text { months, } 24.8 \% \\
22 \text { months, } 20.5 \%\end{array}$ \\
\hline Shahar et al. (26) & $\begin{array}{l}\text { Hospitals of } \\
\text { Minneapolis-St. } \\
\text { USA }\end{array}$ & $\begin{array}{l}2257 \\
1825\end{array}$ & $\begin{array}{l}1995 \\
2000\end{array}$ & & $\begin{array}{l}6 \text { months, M: } 27 \% \text {, F: } 21 \% \\
1 \text { year, M: } 36 \%, \text { F: } 27 \% \\
6 \text { months, M: } 21 \% \text {, F: } 18 \% \\
1 \text { year, M: } 27 \% \text {, F: } 27 \%\end{array}$ \\
\hline
\end{tabular}

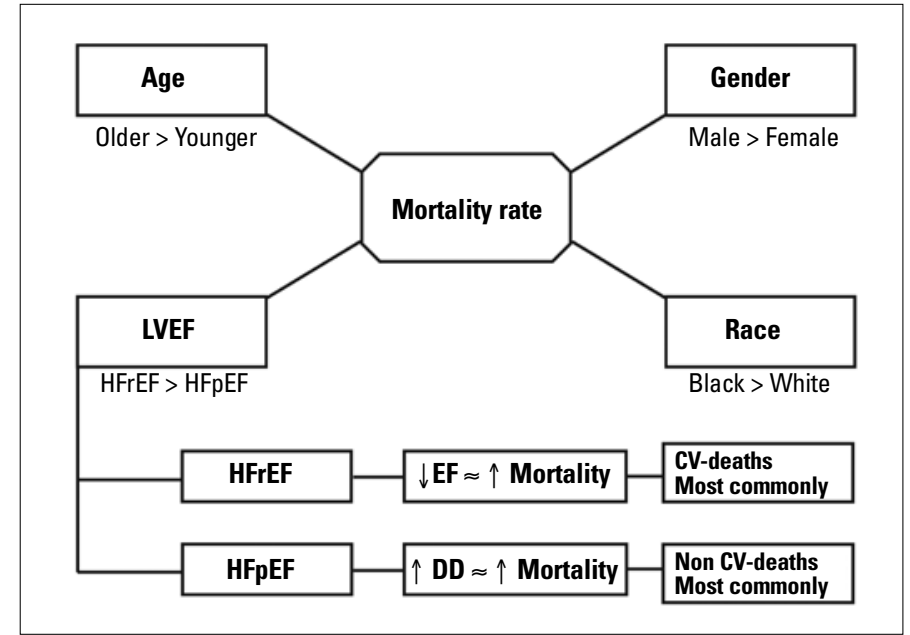

Figure 1. CV - cardiovascular; DD - diastolic dysfunction; EF - ejection fraction; HFpEF - heart failure with preserved ejection fraction; HFrEF heart failure with reduced ejection fraction; LVEF - left ventricular ejection fraction

in 2002-2007 (8). Moreover, Blackledge et al. (24) showed that, similarly to other countries, the hospital mortality rate decreased in England from 25\% during the 1993-1994 to 20\% during 20002001 years. In Sweden, Schaufelberger et al. (25), also reported trends toward decreasing hospital mortality due to HF, from 1988 to 2000 , but the decrease rate was more evident among patients of younger age. In this study, between 1988 and 2000, 1-year mortality declined from $9 \%$ in men and $10 \%$ in women $45-54$ years of age and $4 \%$ and $5 \%$, respectively among men and women among 75-84 years of age. Contrary to this study, Kosiborod et al. (26) found no substantial improvement in mortality, during the 1990s particularly among elderly patients hospitalized with HF. In this study, 30-day mortality $(11.0 \%$ to $10.3 \%)$ and 1 -year $(32.5 \%$ to $31.7 \%)$ in-hospital mortality did not change significantly during the study period between 1992 and 1999.

Mortality in HF patients in relation to age, gender and race

There are differences in mortality of patients with HF in groups according age, gender and race (Fig. 1) (2). The earlier studies have shown that mortality rate in HF patients is agedependent and it increases progressively with the advancing age (27-30). As the life of expectancy lengthened in recent years in Western Countries, the mean age of patients at the time of death increased in last decade: from $70 \pm 9$ years, before 1980 , to $81 \pm 9$ years after1980 (27). Saczynski et al. (28) found that inhospital death rates increased from $3 \%$ in patients younger than 65 years to $8.2 \%$ in those older than 75 years. In addition, the study of Wong et al. (29), also demonstrated that mortality rate increased by increasing patients' age. In this study, 3-year mortality of HF patients increased parallel to the age of patients at the time of their admission for symptomatic HF: $12 \%$ (for the age group $20-39$ years), $13 \%$ (for the age group $40-49$ years), $13 \%$ (for the age group $50-59$ years), $19 \%$ (for the age group $60-69$ years) and $31 \%$ (for the age group $\geq 70$ years). In contrast, Rodriguez et 
Table 3. The mortality rate in patients with heart failure male vs. female

\begin{tabular}{|c|c|c|c|c|c|c|c|}
\hline Author & Study & $\begin{array}{c}\text { Period of } \\
\text { time }\end{array}$ & $\begin{array}{c}\text { Follow } \\
\text { up }\end{array}$ & $\begin{array}{c}\text { Number of } \\
\text { patients }\end{array}$ & $\begin{array}{l}\text { Mortality } \\
\text { in males }\end{array}$ & $\begin{array}{l}\text { Mortality } \\
\text { in females }\end{array}$ & $\boldsymbol{P}$ \\
\hline Rathore et al. (31) & $\begin{array}{l}\text { NHF Project, } \\
\text { USA } \\
\text { (Population Based } \\
\text { cohort) }\end{array}$ & 1998-1999 & & 30996 & $\begin{array}{l}30 \text { day: } 11.4 \% \\
1 \text { year: } 43.0 \%\end{array}$ & $\begin{array}{l}30 \text { day: } 9.2 \% \\
1 \text { year: } 36.2 \%\end{array}$ & $\begin{array}{l}<0.001 \\
<0.001\end{array}$ \\
\hline Parashar et al. (32) & $\begin{array}{l}\text { CHS } \\
\text { Forsyth Country, } \\
\text { North Carolina }\end{array}$ & 1989-1993 & 3 years & 1264 & $\begin{array}{c}\text { White: } 35.5 / 100 \\
\text { American-African: } \\
\text { 33.6/100 }\end{array}$ & $\begin{array}{c}\text { White: } 44.4 / 100 \\
\text { American-African: } \\
40.5 / 100\end{array}$ & \\
\hline Roger et al. (17) & $\begin{array}{l}\text { Olmsted Country, MN } \\
\text { (Population } \\
\text { based cohort) }\end{array}$ & $1996-2000$ & $\begin{array}{c}4.2 \text { years } \\
\text { (mean) }\end{array}$ & & $\begin{array}{l}1 \text { year: } 21 \% \\
5 \text { years: } 50 \%\end{array}$ & $\begin{array}{c}1 \text { year: } 17 \% \\
5 \text { years: } 46 \%\end{array}$ & $\begin{array}{l}<0.001 \\
<0.001\end{array}$ \\
\hline Sakata et al. (35) & $\begin{array}{l}\text { CHART-2 Study } \\
\text { Japan } \\
\text { Prospective study }\end{array}$ & $2006-2010$ & $\begin{array}{c}3.1 \text { years } \\
\text { (mean) }\end{array}$ & 4736 & $47.3 / 1000$ & $52.4 / 1000$ & 0.22 \\
\hline
\end{tabular}

al. (30), using data from the 2007-2008 Healthcare Cost and Utilization Project, found an U-shaped pattern of mortality across the ages for men with mortality rates for age groups $<25,25-64$, and $>64$ years being $2.9 \%, 1.4 \%$, and $3.8 \%$, respectively.

Moreover, several studies showed that mortality was different in male vs. female patients with HF (Table 3), (17, 31-34). In the study by Rathore et al. (32), the mortality rate was lower in female patients than in male US patients with HF during time period between 1998 and 1999. In this study, the 30-day mortality was $9.2 \%$, in female patients versus $11.4 \%$ in male patients $(p<0.001)$. Similarly, 1 -year mortality was $36.2 \%$ in females versus $43.0 \%$ in males $(p<0.001)$. The cohort study by Vaartjes et al. (33), which was based on the National Cause of Death Registry, showed that mortality risk for $\mathrm{HF}$ is higher among men than women. One-year mortality risk was $17 \%$ in men and $14 \%$ in women younger than 55 years, and $58 \%$ in men and $49 \%$ in women older than 85 years. However, the 5 -year mortality risk in these patients did not differ between genders. Few epidemiological data have also shown that the mortality rate in patients with HF did not differ according to gender $(34,35)$.

Racial or ethnic differences in the mortality among patients with HF have been reported. It has been reported that mortality in African American patients was higher than in white patients (2). From the Atherosclerosis Risk in Communities (ARIC) study, the 2-year mortality rates were similar for white and African- American patients, but 5-year mortality rate was higher among AfricanAmerican male ( $52 \%$ vs. $41 \%, \mathrm{p}=0.02)$ and female $(46 \%$ vs. $36 \%$, $\mathrm{p}=0.03$ ) patients compared with white patients with $\mathrm{HF}(36)$.

\section{Mortality rate in HFrEF compared HFpEF}

In general, the mortality rate of patients with HFpEF varied substantially across the studies (7). Many cohort studies reported lower mortality in HFpEF patients compared with HFrEF patients (Table 4) $(8,37)$. Smith et al. (38) found that patients with
HFrEF had a higher death rate during six months of follow-up compared with $\mathrm{HFpEF}$ patients ( $21 \%$ vs. $13 \% ; p=0.02)$. Along the same lines, the Veterans Administration Heart Failure Trial (V-HeFT) showed that the annual mortality was higher in HFrEF compared with HFpEF patients ( $19 \%$ vs. $8 \%, p=0.0001)$ (39). Similarly, the study by Tribouilloy et al. (40), showed that patients with reduced EF had higher in-hospital mortality rate than those with preserved ( $8.2 \%$ vs. $2.7 \%, p=0.002$ ). Similarly, a meta-analysis of 17 studies of HF patients with a total of 24501 patients, by Somaratne et al. (41) also showed that there is difference in mortality between these two groups of patients. In this study, after 47 months of follow-up period (starting in 2006), the mortality rate among patients with $\mathrm{HFrEF}$ was $40.6 \%$ compared with $32.1 \%$ among HFpEF patients. In regard to age, Kerzner et al. (42) found that mortality rate in elderly HFrEF patients was higher compared with $\mathrm{HFpEF}(53.9 \%$ vs. $35.8 \%, \mathrm{p}=0.03)$, whereas in patients older than 75 years, the difference in mortality rates between groups was not significant (38.5\% vs. $29.6 \%, \mathrm{p}=0.22)$.

On the other hand, several epidemiological cohort studies reported similar mortality rates in patients with $\mathrm{HFpEF}$ and $\mathrm{HFrEF}$ (43-45). Bhatia et al. (44) based on the data from 103 hospitals in the province of Ontario, Canada during the 1999-2001 period, demonstrated that mortality rate in these two types of $\mathrm{HF}$ was similar: 1 year mortality in $\mathrm{HFrEF}$ was $26 \%$ compared to $22 \%$ in $\mathrm{HFpEF}$ $(p=0.07)$. More recently, Quiroz et al. (45) noted that 30 -day and 1 -year mortality rates were not different between HFrEF and HFpEF groups $(3.0 \%$ versus $E F$ versus $2.7 \%, p=0.74$ for 30 -day mortality and $18.2 \%$ versus $17.1 \%, \mathrm{p}=0.34$ for 1 -year mortality, respectively).

Several studies have shown that the mortality rate among patients with HFrEF correlates closely with the level of reduced left ventricular EF $(46,47)$. Curtis et al. (47) based on the Digitalis Investigation Group (DIG) trial showed that the mortality rate increased proportionally with the decrease in the left ventricular EF. In this study, the mortality rates among patients group with left 
Table 4. The mortality in patients with HFrEF vs. HFpEF

\begin{tabular}{|c|c|c|c|c|c|c|c|}
\hline Author & Study & $\begin{array}{l}\text { Period of } \\
\text { time }\end{array}$ & $\begin{array}{l}\text { Follow } \\
\text { up }\end{array}$ & $\begin{array}{c}\text { Number of } \\
\text { patients }\end{array}$ & $\begin{array}{l}\text { Mortality } \\
\text { in HFrEF }\end{array}$ & $\begin{array}{l}\text { Mortality } \\
\text { in HFpEF }\end{array}$ & $\boldsymbol{P}$ \\
\hline Gottdiener et al. (41) & CHS, USA & 1989-1993 & 6.4 years & 300 & 6 year: $54 \%$ & 6 year: $43 \%$ & $<0.001$ \\
\hline Smith et al. (37) & $\begin{array}{l}\text { Yale-New Haven } \\
\text { Hospital Center }\end{array}$ & 1996-1998 & 6 months & 413 & 6 months: $21 \%$ & 6 months: $13 \%$ & 0.02 \\
\hline Kerzner et al. (42) & $\begin{array}{l}\text { SSA Death Registry } \\
\text { Washington, USA }\end{array}$ & 1999-2001 & $\begin{array}{c}25 \text { months } \\
\text { (mean) }\end{array}$ & 373 & $\begin{array}{r}\text { Age }<75 y: 38.5 \% \\
\text { Age } \geq 75 \text { y: } 53.9 \%\end{array}$ & $\begin{array}{l}\text { Age }<75 y: 29.6 \% \\
\text { Age } \geq 75 \text { y:35.8\% }\end{array}$ & $\begin{array}{l}0.22 \\
0.03 \\
\end{array}$ \\
\hline Tribouilloy et al. (39) & $\begin{array}{l}\text { Framingham } \\
\text { Criteria, France }\end{array}$ & 2000 & 1 year & 799 & $8.20 \%$ & $2.70 \%$ & 0.002 \\
\hline Bhatia et al. (44) & $\begin{array}{l}\text { EFFECT study } \\
\text { Ontario, Canada }\end{array}$ & 1999-2001 & 1 year & 2802 & $\begin{array}{c}30 \text { days: } 7.0 \% \\
1 \text { year: } 26 \%\end{array}$ & $\begin{array}{c}30 \text { days: } 5.0 \% \\
1 \text { year: } 22 \%\end{array}$ & $\begin{array}{l}0.08 \\
0.07\end{array}$ \\
\hline Quiroz et al. (45) & $\begin{array}{l}\text { BMC, USA } \\
\text { GWTG registry }\end{array}$ & 2006-2008 & 22 months & 1097 & $\begin{array}{l}30 \text { days: } 3.0 \% \\
1 \text { year: } 18.2 \%\end{array}$ & $\begin{array}{c}30 \text { days: } 2.7 \% \\
17.10 \%\end{array}$ & $\begin{array}{l}0.74 \\
0.34\end{array}$ \\
\hline
\end{tabular}

ventricular $\mathrm{EF}<15 \%, 16-25 \%, 26-35 \%$ and $36-45 \%$ were $51 \%$, $41.7 \%, 31.4 \%$ and $25.6 \%$, respectively. The mortality rates, however, were comparable among patients with $\mathrm{HFpEF}(23.3 \%$ among patients with left ventricular EF $46-55 \%$ versus $23.5 \%$ among patients with left ventricular $>55 \% ; \mathrm{p}=0.25$ ). Redfield et al. (48) described a relationship between the degree of diastolic dysfunction and mortality in HFpEF. Mortality rate in HFpEF increased as the degree of diastolic dysfunction increased. Compared to nor$\mathrm{mal}$, mild diastolic dysfunction increased the risk of death by 8.3 fold $(p<0.001)$ and moderate to severe diastolic dysfunction increased the risk of mortality by 10.2 fold $(p<0.001)$.

The mode of death is also different between the two groups of patients. Among patients with reduced $\mathrm{EF}$, death was due to cardiovascular causes in $64 \%$ of deaths $(43 \%$ coronary heart disease and $21 \%$ other cardiovascular causes) and to non-cardiovascular causes in $36 \%$. In contrast, deaths among patients with preserved EF were most commonly due to non-cardiovascular causes ( $49 \%$ of all deaths) followed by coronary artery disease $(29 \%)$ and other cardiovascular $(22 \%)$ causes (49). Similarly, Hamaguchi et al. (50) also showed that mortality from non-cardiovascular causes was significantly higher among HFpEF than among patients with HFrEF (28\% vs. $18 \%, p=0.02)$. In particular, cardiovascular causes including sudden death, were more frequent among patients with reduced EF compared with patients with preserved $\mathrm{EF}(68 \%$ vs. $58 \%, \mathrm{p}=0.02)$.

\section{Conclusion}

Despite the impressive achievements in the pharmacological and non-pharmacological treatment of HF patients which has undeniably improved the survival of these patients, the mortality still remains high particularly among elderly, male and African American patients. HFrEF patients have higher mortality rates, most commonly due to cardiovascular causes, compared with patients with HFpEF.

Conflict of interest: None declared.

\section{References}

1. Roger VL. Epidemiology of heart failure. Circ Res 2013; 113: 64659. [CrossRef]

2. Bui AL, Horwich TB, Fonarow GC. Epidemiology and risk profile of heart failure. Nat Rev Cardiol 2011; 8: 30-41. [CrossRef]

3. Mosterd A, Hoes AW. Clinical epidemiology of heart failure. Heart 2007; 93: 1137-46. [CrossRef]

4. Loh JC, Creaser J, Rourke DA, Livingston N, Harrison TK, Vandenbogaart $\mathrm{E}$, et al. Temporal trends in treatment and outcomes for advanced heart failure with reduced ejection fraction from 1993-2010: findings from a university referral center. Circ Heart Fail 2013; 6: 411-9. [CrossRef]

5. Lee DS, Gona P, Vasan RS, Larson MG, Benjamin EJ, Wang TJ, et al. Relation of disease etiology and risk factors to heart failure with preserved or reduced ejection fraction. Circulation 2009; 119: 3070-7. [CrossRef]

6. Owan TE, Redfield MM. Epidemiology of diastolic heart failure. Prog Cardiovasc Dis 2005; 47: 320-32. [CrossRef]

7. Lam CS, Donal E, Kraigher-Krainer E, Vasan RS. Epidemiology and clinical course of heart failure with preserved ejection fraction. Eur J Heart Fail 2011; 13: 18-28. [CrossRef]

8. Dunlay SM, Redfield MM, Weston SA, Therneau TM, Hall Long K, Shah ND, et al. Hospitalizations after heart failure diagnosis a community perspective. J Am Coll Cardiol 2009; 54: 1695-702. [CrossRef]

9. Rohde LE, Bertoldi EG, Goldraich L, Polanczyk CA. Costeffectiveness of heart failure therapies. Nat Rev Cardiol 2013; 10: 338-54. [CrossRef]

10. Friedrich EB, Böhm M. Management of end-stage heart failure. Heart 2007; 93: 626-31. [CrossRef]

11. Levy D, Kenchaiah S, Larson MG, Benjamin EJ, Kupka MJ, Ho KK, et al. Long-term trends in the incidence of and survival with heart failure. N Engl J Med 2002; 347: 1397-402. [CrossRef]

12. Mosterd A, Cost B, Hoes AW, de Bruijne MC, Deckers JW, Hofman $A$, et al. The prognosis of heart failure in the general population: The Rotterdam Study. Eur Heart J 2001; 22: 1318-27. [CrossRef]

13. Gomez-Soto FM, Andrey JL, Garcia-Egido AA, Escobar MA, Romero SP, Garcia-Arjona $R$, et al. Incidence and mortality of heart failure: a community-based study. Int J Cardiol 2011; 151: 40-5. [CrossRef] 
14. Mehta PA, Dubrey SW, McIntyre HF, Walker DM, Hardman SM, Sutton $\mathrm{GC}$, et al. Improving survival in the 6 months after diagnosis of heart failure in the past decade: population-based data from the UK. Heart 2009; 95: 1851-6. [CrossRef]

15. Laribi S, Aouba A, Nikolaou M, Lassus J, Cohen-Solal A, Plaisance P, et al. Trends in death attributed to heart failure over the past two decades in Europe. Eur J Heart Fail 2012; 14: 234-9. [CrossRef]

16. Feinglass J, Martin GJ, Lin E, Johnson MR, Gheorghiade M. Is heart failure survival improving? Evidence from 2323 elderly patients hospitalized between 1989-2000. Am Heart J 2003; 146: 111-4. [CrossRef]

17. Roger VL, Weston SA, Redfield MM, Hellermann-Homan JP, Killian J, Yawn BP, et al. Trends in heart failure incidence and survival in a community-based population. JAMA 2004; 292: 344-50. [CrossRef]

18. Barker WH, Mullooly JP, Getchell W. Changing incidence and survival for heart failure in a well-defined older population, 1970-1974 and 1990-1994. Circulation 2006; 113: 799-805. [CrossRef]

19. Reitsma JB, Mosterd A, de Craen AJ, Koster RW, van Capelle FJ, Grobbee $\mathrm{DE}$, et al. Increase in hospital admission rates for heart failure in The Netherlands, 1980-1993. Heart 1996; 76: 388-92. [CrossRef]

20. Shahar $\mathrm{E}$, Lee $\mathrm{S}$. Historical trends in survival of hospitalized heart failure patients: 2000 versus 1995. BMC Cardiovasc Disord 2007; 7: 2. [CrossRef]

21. Fang J, Mensah GA, Croft JB, Keenan NL. Heart failure-related hospitalization in the U.S., 1979 to 2004. J Am Coll Cardiol 2008; 52: 428-34. [CrossRef]

22. Blecker S, Paul M, Taksler G, Ogedegbe G, Katz S. Heart failure-associated hospitalizations in the United States. J Am Coll Cardiol 2013; 61: 1259-67. [CrossRef]

23. Bueno H, Ross JS, Wang Y, Chen J, Vidán MT, Normand SL, et al. Trends in length of stay and short-term outcomes among medicare patients hospitalized for heart failure: 1993-2008. JAMA 2010; 303: 2141-7. [CrossRef]

24. Blackledge HM, Tomlinson J, Squire IB. Prognosis for patients newly admitted to hospital with heart failure: survival trends in 12220 index admissions in Leicestershire 1993-2001. Heart 2003; 89: 615-20. [CrossRef]

25. Schaufelberger $M$, Swedberg $K$, Köster $M$, Rosén $M$, Rosengren $A$. Decreasing one-year mortality and hospitalization rates for heart failure in Sweden; Data from the Swedish Hospital Discharge Registry 1988 to 2000. Eur Heart J 2004; 25: 300-7. [CrossRef]

26. Kosiborod M, Lichtman JH, Heidenreich PA, Normand SL, Wang Y, Brass $\mathrm{LM}$, et al. National trends in outcomes among elderly patients with heart failure. Am J Med 2006; 119: 616-7. [CrossRef]

27. Lee DS, Gona P, Albano I, Larson MG, Benjamin EJ, Levy D, et al. A systematic assessment of causes of death after heart failure onset in the community: impact of age at death, time period, and left ventricular systolic dysfunction. Circ Heart Fail 2011; 4: 36-43. [CrossRef]

28. Saczynski JS, Darling CE, Spencer FA, Lessard D, Gore JM, Goldberg RJ. Clinical features, treatment practices, and hospital and long-term outcomes of older patients hospitalized with decompensated heart failure: The Worcester HeartFailure Study. J Am Geriatr Soc 2009; 57: 1587-94. [CrossRef]

29. Wong CM, Hawkins NM, Jhund PS, MacDonald MR, Solomon SD, Granger $\mathrm{CB}$, et al. Clinical characteristics and outcomes of young and very young adults with heart failure: The CHARM programme (Candesartan in Heart Failure Assessment of Reduction in Mortality and Morbidity). J Am Coll Cardiol 2013; 62: 1845-54. [CrossRef]

30. Rodriguez F, Wang Y, Johnson CE, Foody JM. National patterns of heart failure hospitalizations and mortality by sex and age. J Card Fail 2013; 19: 542-9. [CrossRef]

31. Parashar S, Katz R, Smith NL, Arnold AM, Vaccarino V, Wenger NK, et al. Race, gender, and mortality in adults $>$ or $=65$ years of age with incident heart failure (from the Cardiovascular Health Study). Am J Cardiol 2009; 103: 1120-7. [CrossRef]

32. Rathore SS, Foody JM, Wang Y, Herrin J, Masoudi FA, Havranek EP, et al. Sex, quality of care, and outcomes of elderly patients hospitalized with heart failure: findings from the National Heart Failure Project. Am Heart J 2005; 149: 121-8. [CrossRef]
33. Vaartjes I, Hoes AW, Reitsma JB, de Bruin A, Grobbee DE, Mosterd A, et al. Age- and gender-specific risk of death after first hospitalization for heart failure. BMC Public Health 2010; 10: 637. [CrossRef]

34. Jiménez-Navarro MF, Ramirez-Marrero MA, Anguita-Sánchez M, Castillo JC. Influence of gender on long-term prognosis of patients with chronic heart failure seen in heart failure clinics. Clin Cardiol 2010; 33: 13-8. [CrossRef]

35. Sakata Y, Miyata S, Nochioka K, Miura M, Takada T, Tadaki S, et al. Gender differences in clinical characteristics, treatment and long-term outcome in patients with stage $\mathrm{C} / \mathrm{D}$ heart failure in Japan. Report from the CHART-2 study. Circ J 2014; 78: 428-35. [CrossRef]

36. Loehr LR, Rosamond WD, Chang PP, Folsom AR, Chambless LE. Heart failure incidence and survival (from the Atherosclerosis Risk in Communities study). Am J Cardiol 2008; 101: 1016-22. [CrossRef]

37. Gottdiener JS, McClelland RL, Marshall R, Shemanski L, Furberg CD, Kitzman DW, et al. Outcome of congestive heart failure in elderly persons: influence of left ventricular systolic function. The Cardiovascular Health Study. Ann Intern Med 2002; 137: 631-9. [CrossRef]

38. Smith GL, Masoudi FA, Vaccarino V, Radford MJ, Krumholz HM. Outcomes in heart failure patients with preserved ejection fraction: mortality, readmission, and functional decline. J Am Coll Cardiol 2003; 41: 1510-8. [CrossRef]

39. Cohn JN, Johnson G. Heart failure with normal ejection fraction. The V-HeFT Study. Veterans Administration Cooperative Study Group. Circulation 1990; 81: 48-53.

40. Tribouilloy C, Rusinaru D, Leborgne L, Mahjoub H, Szymanski C, Houpe D, et al. In-hospital mortality and prognostic factors in patients admitted for newonset heart failure with preserved or reduced ejection fraction: a prospective observational study. Arch Cardiovasc Dis 2008; 101: 226-34. [CrossRef]

41. Somaratne JB, Berry C, McMurray JJ, Poppe KK, Doughty RN, Whalley $\mathrm{GA}$. The prognostic significance of heart failure with preserved left ventricular ejection fraction: a literature-based meta-analysis. Eur $\mathrm{J}$ Heart Fail 2009; 11: 855-62. [CrossRef]

42. Kerzner R, Gage BF, Freedland KE, Rich MW. Predictors of mortality in younger and older patients with heart failure and preserved or reduced left ventricular ejection fraction. Am Heart J 2003; 146: 286-90. [CrossRef]

43. Bursi F, Weston SA, Redfield MM, Jacobsen SJ, Pakhomov S, Nkomo VT, et al. Systolic and diastolic heart failure in the community. JAMA 2006; 296: 2209-16. [CrossRef]

44. Bhatia RS, Tu JV, Lee DS, Austin PC, Fang J, Haouzi A, et al. Outcome of heart failure with preserved ejection fraction in a population-based study. N Engl J Med 2006; 355: 260-9. [CrossRef]

45. Quiroz R, Doros G, Shaw P, Liang CS, Gauthier DF, Sam F. Comparison of characteristics and outcomes of patients with heart failure preserved ejection fraction versus reduced left ventricular ejection fraction in an urban cohort. Am J Cardiol 2014; 113: 691-6. [CrossRef]

46. Tarantini L, Faggiano P, Senni M, Lucci D, Bertoli D, Porcu M, et al. Clinical features and prognosis associated with a preserved left ventricular systolic function in a large cohort of congestive heart failure outpatients managed by cardiologists. Data from the Italian Network on Congestive Heart Failure. Ital Heart J 2002; 3: 656-64.

47. Curtis JP, Sokol SI, Wang Y, Rathore SS, Ko DT, Jadbabaie F, et al. The association of left ventricular ejection fraction, mortality, and cause of death in stable outpatients with heart failure. J Am Coll Cardiol 2003; 42: 736-42. [CrossRef]

48. Redfield MM, Jacobsen SJ, Burnett JC Jr, Mahoney DW, Bailey KR, Rodeheffer RJ. Burden of systolic and diastolic ventricular dysfunction in the community: appreciating the scope of the heart failure epidemic. JAMA 2003; 289: 194-202. [CrossRef]

49. Henkel DM, Redfield MM, Weston SA, Gerber Y, Roger VL. Death in heart failure: a community perspective. Circ Heart Fail 2008; 1: 91-7. [CrossRef]

50. Hamaguchi S, Kinugawa S, Sobirin MA, Goto D, Tsuchihashi-Makaya M, Yamada S, et al. Mode of death in patients with heart failure and reduced vs. preserved ejection fraction: report from the registry of hospitalized heart failure patients. Circ J 2012; 76: 1662-9. [CrossRef] 